\title{
A changing distribution of seabirds in South Africa - the possible impact of climate and its consequences
}

\author{
Robert J. M. Crawford ${ }^{1,2 *}$, Azwianewi B. Makhado ${ }^{1}$, Philip A. Whittington ${ }^{3,4}$, Rod M. Randall , \\ W. Herman Oosthuizen ${ }^{1}$ and Lauren J. Waller ${ }^{6}$ \\ ${ }^{1}$ Branch Oceans and Coasts, Department of Environmental Affairs, Cape Town, South Africa \\ ${ }^{2}$ Animal Demography Unit, Department of Natural Sciences, University of Cape Town, Rondebosch, South Africa \\ ${ }^{3}$ Department of Zoology, Nelson Mandela Metropolitan University, Port Elizabeth, South Africa \\ ${ }^{4}$ East London Museum, Southernwood, South Africa \\ ${ }^{5}$ South African National Parks, Sedgefield, South Africa \\ ${ }^{6}$ CapeNature, Hermanus, South Africa
}

\section{Edited by:}

Morten Frederiksen, Aarhus

University, Denmark

Reviewed by:

Nathaniel K. Newlands, Federal Government of Canada, Canada Debbie Russell, University of St Andrews, UK

${ }^{*}$ Correspondence:

Robert J. M. Crawford, Branch Oceans and Coasts, Department of Environmental Affairs, Second Floor, Foretrust Building, Martin Hammerschlag Road, Foreshore,

Cape Town 8001, South Africa

e-mail: crawford@

environment.gov.za
In the southern Benguela ecosystem off South Africa, there were recent shifts to the south and east in the distributions of three forage resources (anchovy, sardine, rock lobster), which probably were influenced by environmental change although fishing too may have played a part. In this study, we review information on trends in distributions and numbers of eight seabirds breeding in South Africa. For five species that feed predominantly on anchovy, sardine or rock lobster, their populations off northwest South Africa decreased markedly. For three of these species, which exhibit behavioral inertia and have restricted foraging ranges when breeding (African penguin, Cape cormorant, bank cormorant), there were large decreases in their overall populations in South Africa. Conversely, for two showing more plasticity and able to range over wide areas or move between breeding localities (Cape gannet, swift tern) there were increases. It is thought that movement of forage resources away from the northern islands led to a mismatch in the distributions of breeding localities and prey of dependent seabirds off western South Africa and to attempts by several species to establish colonies on the southern mainland closer to food resources. There also were shifts to the south and east in the distributions of three seabirds that do not compete with fisheries for prey (crowned cormorant, white-breasted cormorant, kelp gull), suggesting some environmental forcing, but decreases of these species off northwest South Africa were less severe and populations in South Africa remained stable or increased in the long term. It is likely, because many fishing plants are located in the northwest, that there was increased competition between seabirds and fisheries for prey as forage resources moved south and east. Potential interventions to mitigate the adverse impacts of distributional changes for seabirds include allocations of allowable catches of shared forage resources at regional levels, closures to fishing around impacted seabird colonies and establishment of new colonies nearer to the present location of food.

Keywords: behavioral inertia, Benguela ecosystem, competition with fisheries, distributional change, environmental forcing, forage resources, mainland breeding, seabirds

\section{INTRODUCTION}

Marine ecosystems are being affected by climate change worldwide. Often such change is pronounced at high latitudes, where its impact on associated fauna is readily apparent. For example, reductions in stable old ice, increases in unconsolidated ice and lengthening of the melt season in the Arctic Ocean have reduced the availability and quality of denning habitat in pack ice for polar bears (Ursus maritimus) and caused an increase of bears denning in coastal habitat, thereby altering their distribution (Fischbach et al., 2007). In the West Antarctic Peninsula, there have been poleward shifts in ice extent and local declines of ice-dependent Adélie penguins (Pygoscelis adeliae) (Trivelpiece et al., 2011; Lynch et al., 2012), which contrast with increases and a southward range extension of Gentoo penguins (P. papua) that do not depend on ice (Lynch, 2013). At lower latitudes changes in distributions of marine fauna also may be pronounced (Cheung et al., 2009), but sometimes the reasons for these and altered population trends are not as clearly understood. Thus, eight potential causes were postulated for circumpolar decreases of sub-Antarctic rockhopper penguins (Eudyptes chrysocome and E. moseleyi) (BirdLife International, 2010).

Off South Africa, in the southern Benguela ecosystem there have been recent changes in the distributions and population sizes of several animals, including seabirds (e.g., Whittington, 2004; Crawford et al., 2007, 2014b; Kirkman et al., 2012; Crawford, 2013) and three forage species that are important prey for 
seabirds: anchovy (Engraulis encrasicolus), sardine (Sardinops sagax) and rock lobster (Jasus lalandii) (van der Lingen et al., 2006; Blamey et al., 2015). From 1984 to 1995 most (61 $\pm 21 \%$ by mass standard deviation) spawning anchovy were located west of Cape Agulhas (Figure 1), whereas from 1996 to 2005 this proportion halved to $31 \pm 11 \%$ (information in Roy et al., 2007). From 1994 to 1998 most ( $74 \pm 17 \%$ by mass) spawning sardine were west of Cape Agulhas, but this decreased by two-thirds to 26 $\pm 12 \%$ from 1999 to 2007 (information in Coetzee et al., 2008). Catches of sardine similarly showed a marked shift to the south and east; their center of gravity was near Dassen Island in 1997 but off Mossel Bay, east of Cape Agulhas, in 2005 (Fairweather et al., 2006; Figure 1). During the 1990s there also was a notable change in the proportions of South African catches of rock lobster taken to the north and south of Dassen Island (Figure 1). Before the 1990s most of the catch was taken to the north, subsequently most was taken to the south with this proportion attaining $70 \%$ by 2010 (Blamey et al., 2012). The changed distribution of catches of rock lobster reflects an altered distribution of the species and an eastward expansion of its range to the Stony Point region (Figure 1A) and beyond (Tarr et al., 1992; Cockcroft and MacKenzie, 1997; Cockcroft et al., 2008).

There is accumulating evidence that an altered environment, possibly driven by climate change, is driving these changes (e.g., Gammelsrød et al., 1998; Roy et al., 2007; Cockcroft et al., 2008). However, ultimate causes of environmental change remain difficult to attribute, and it is unknown to what extent it may be reversible (Hutchings et al., 2009; Moloney et al., 2013). Furthermore, it is frequently difficult to disentangle the influence of the environment from anthropogenic impacts, such as fishing (e.g., Coetzee et al., 2008). However, in the Benguela ecosystem several studies have demonstrated relationships between the abundance of prey and numbers of breeding seabirds or their demographic parameters, such as breeding success and survival (e.g., Crawford et al., 2006, 2007, 2011; Crawford, 2007; Sabarros et al., 2012; Sherley et al., 2013, 2014). Therefore, it may be expected that factors influencing the distribution of prey species, and hence its regional availability, will impact on seabirds.

In the South African situation, African penguin (Spheniscus demersus), Cape gannet (Morus capensis), Cape cormorant

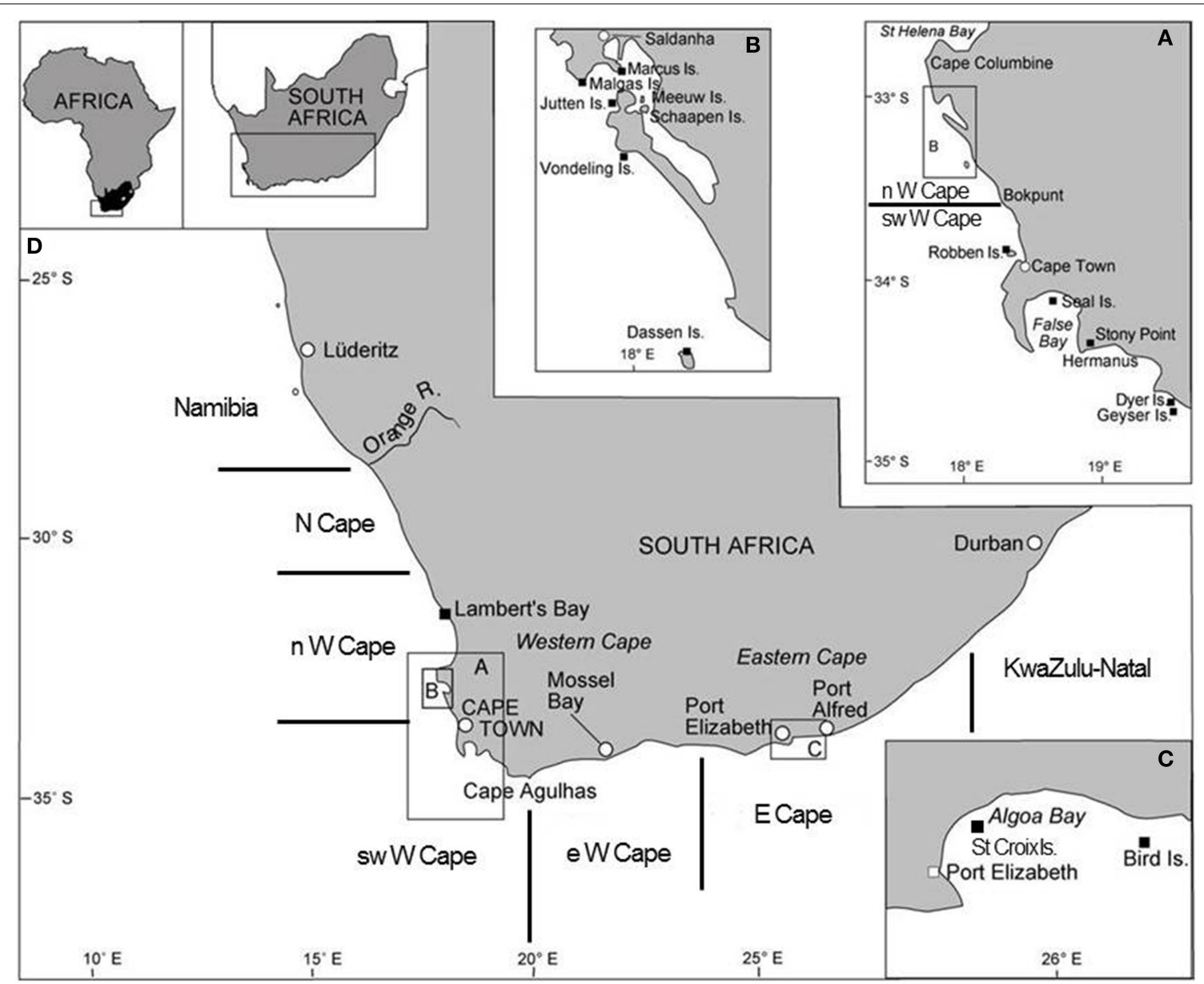

FIGURE 1 | Map of South Africa showing several of the important seabird breeding localities (amended from Crawford et al., 2014b). Boundaries of the five South African regions considered in this study are indicated. 
(Phalacrocorax capensis), bank cormorant (P. neglectus) and swift tern (Thalasseus bergii) compete with fisheries for food, whereas other seabirds, including white-breasted cormorant (P. lucidus), crowned cormorant (Microcarbo coronatus) and kelp gull (Larus dominicanus), show little or no such competition (Hockey et al., 2005). A comparison of these two groups of seabirds may provide insight into the relative importance of factors driving change in their distributions and populations (Crawford et al., 2008d). Therefore, in this paper we review published and unpublished information on recent change in the distributions and population sizes of these eight seabirds, similarities and differences in their responses to recent environmental change, possible causes of different responses and potential means to mitigate adverse impacts of change.

\section{METHODS}

Good information is available for two or three periods between the mid-1970s and the mid-2010s (late 1970s/early 1980s, late 1990s/early 2000s, late 2000s/early 2010s) on the numbers of the above-mentioned eight species of seabird breeding in South Africa and their distributions (see Table 1 for sources of data). The information for white-breasted cormorant, which is sometimes considered a race of the great cormorant $P$. carbo (BirdLife International, 2014), refers only to that portion of the South African population that breeds on the coast and excludes the KwaZulu-Natal coast in the east of the country. Except for white-breasted cormorant, each of the eight seabirds is endemic to the Benguela upwelling system off southwest Africa, although for swift tern and kelp gull only at a sub-specific level (Crawford, 2013). For all species, the counts or estimates of numbers breeding in each period were made using similar methods to those employed in the first period.

For African penguins, numbers of nests in use were counted. A nest was considered to be in use if it contained fresh eggs or chicks, if it was defended by a non-molting adult bird or, because breeding by African penguins is not always synchronous, if it showed recent signs of use, e.g., through the presence of substantial quantities of fresh guano or nesting material (Crawford et al., 2011). Numbers of chicks in crèches were divided by two, the usual clutch size, to estimate the number of nest sites they represented, with remainders taken to represent an additional site, e.g., crèches of five and six chicks would both be taken to represent three nests (Shelton et al., 1984). As is the case for cormorants (see below), because not all eggs hatch and broods may be reduced (e.g., Sherley et al., 2012a), this is likely to underestimate the actual number of nests represented by chicks in crèches and hence lead to a conservative estimate of the overall number of birds breeding. Furthermore, brood reduction may vary depending on conditions during breeding. However, the contribution of nests assumed from counts of chicks in crèches to the overall estimate of numbers breeding was small $(<10 \%$, usually $<5 \%)$.

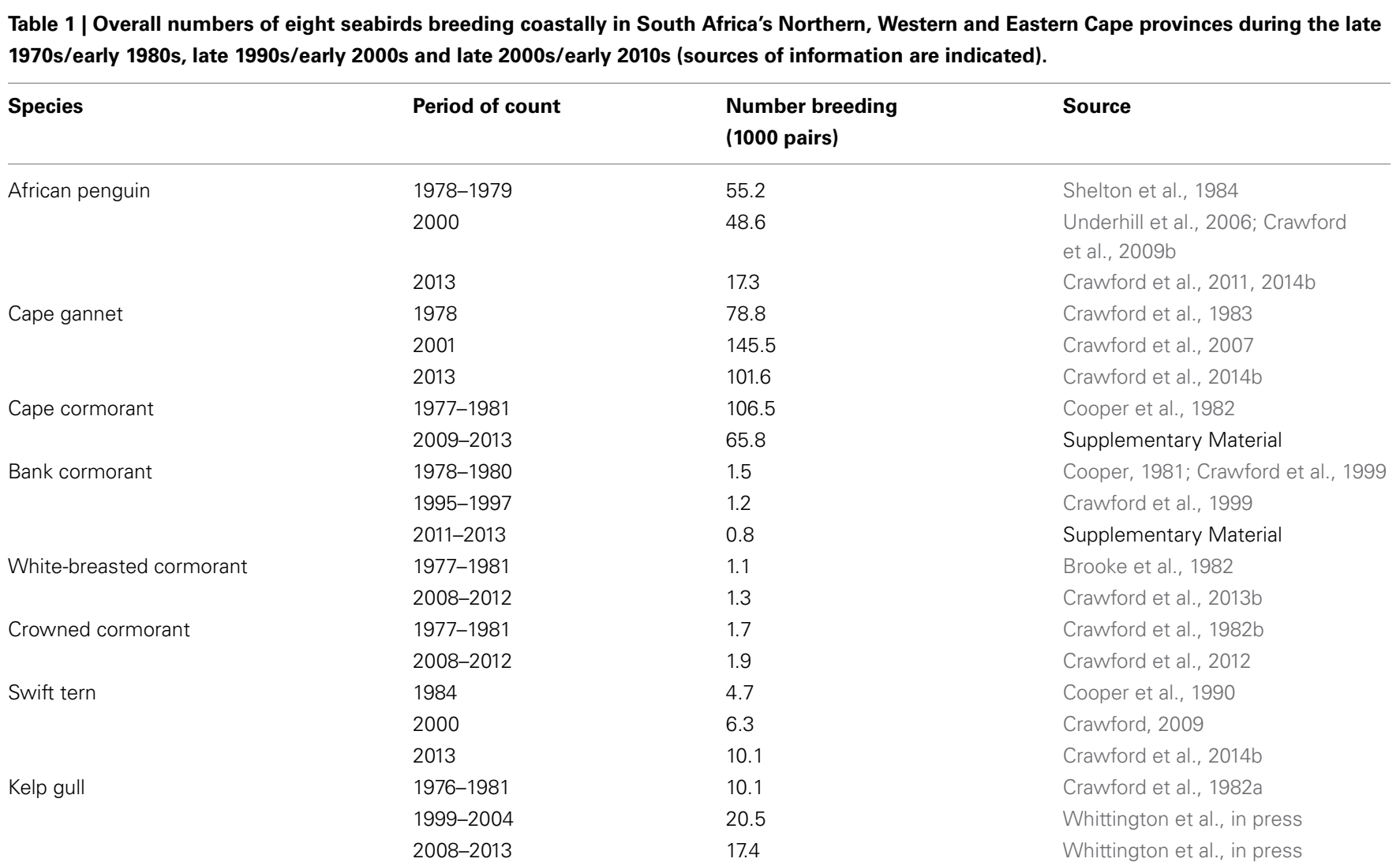

No comparative information for the intermediate period is available for Cape, white-breasted or crowned cormorants. 
For Cape gannets, numbers breeding at colonies were estimated from the product of the area occupied by breeding birds and the mean density of nests (Crawford et al., 2007). The extent of the area occupied by breeders was measured on aerial photographs, taken vertically, using an Ibas interactive image-analysis system, or by walking around the colony with a Global Positioning System (GPS) (Crawford et al., 2007, 2014b). Measurements of the densities of nests at colonies were undertaken toward the end of the breeding season by placing four poles, each $2 \mathrm{~m}$ long, on the surface of the ground, so as to form a square of $4 \mathrm{~m}^{2}$. The numbers of whole nests and part nests within the square were counted. The overall number of nests in the square was taken to be the number of whole nests plus half the number of part nests (Crawford et al., 2007).

For the four species of cormorant, counts were made of active nest sites, which were defined as paired birds defending a site, sites showing evidence of recent nest-construction, and nests with eggs, chicks or adults. When unattended chicks were found in crèches away from nests, their number was divided by the approximate mean clutch size of the species (two for bank cormorant, three for the other cormorants) to estimate the number of nest sites they represented, because nests at which these chicks were reared would not have been counted (Crawford et al., 2008a, 2012, 2013b, 2014b). Remainders were taken to represent further sites. For Cape, white-breasted and crowned cormorants, the highest count at each breeding colony during a 5-year period was taken and the selected counts were then summed to produce the total count for the period. The same process was carried out for bank cormorants but for periods of 3 years. This was done because not all colonies are visited each year and some only sporadically (Cooper, 1981; Cooper et al., 1982; Crawford et al., 1999). Cape and bank cormorants often show strong fidelity to breeding sites, whereas fidelity of whitebreasted and crowned cormorants to sites is weaker (Crawford et al., 1994). This may lead to inflated estimates of numbers of the latter two species but under-counting at colonies also may occur. These biases are discussed more fully in Crawford et al. (2012, 2013b).

For swift terns, numbers of birds incubating eggs or with small chicks were counted with the aid of tally counters and binoculars. Large colonies were divided into smaller portions to facilitate counting (Cooper et al., 1990). Counts of chicks unattended by parents were added to those of breeding birds to estimate the number of pairs breeding, the mean size of swift tern clutches in southern Africa being approximately one (Crawford et al., 2002).

Counts of breeding kelp gulls were made from vantage points using binoculars after gulls had settled at nests, or by walking tightly spaced grids and marking nests (Crawford et al., 1982a; Whittington et al., 2006, in press). Counts took place during the breeding season and at the main colonies they were usually conducted from late October-early November, when birds at most nests were incubating eggs (Crawford et al., 1982a). Kelp gulls incubating eggs are generally easier to count than those that have yet to lay or are guarding chicks, because they remain longer at nests and soon settle at nests after being disturbed. Chicks are able to leave nests shortly after hatching and their cryptic plumage and behavior makes them easy to overlook (Crawford et al., 1982a). Therefore, recently used nests of kelp gulls also were counted.

Based on information in the indicated references, during periods of relative stability of populations the coefficients of variation for annual estimates of overall numbers of birds breeding at wellmonitored colonies were $0.16(n=8)$ for African penguin, 0.10 $(n=12)$ for Cape gannet, $0.14(n=21)$ for Cape cormorant, $0.32(n=14)$ for swift tern (Crawford et al., 2014b), $0.07(n=$ 13) for bank cormorant (Crawford et al., 2008a), $0.15(n=17)$ for white-breasted cormorant (Crawford et al., 2013b), 0.11 ( $n=$ 14) for crowned cormorant (Crawford et al., 2012) and 0.06 $(n=5)$ for kelp gull (Crawford et al., 2009a).

In order to examine changes in the distributions of breeding by the eight seabirds since the late 1970s/1980s, the eastern and southern coasts of South Africa were divided into five regions and the numbers of each seabird breeding in each region were plotted for periods for which information was available. The five regions were the same as those used by Crawford et al. (2013b) and similar to those used by Whittington et al. (in press), viz. the Northern Cape, the north, southwest and east sectors of the Western Cape and the Eastern Cape (Figure 1). In South Africa, seven of the eight species considered breed exclusively in these regions (Hockey et al., 2005). The white-breasted cormorant breeds too in KwaZulu-Natal, but numbers breeding coastally in that province are only available for 2008-2012 (Crawford et al., 2013b).

Following Whittington et al. (in press), changes between periods were also examined in the proportions of the eight seabirds breeding at maritime islands (including rocks and stacks surrounded by the ocean) and on the mainland (including islands in salt-works and estuaries) as seabirds on the mainland are subject to additional threats, such as predation by mainland carnivores (e.g., Crawford et al., 2011). Two sites that were formerly islands but subsequently joined to the mainland (Bird Island at Lambert's Bay in 1959 and Marcus Island in 1976) were considered mainland sites because the earliest counts considered here commenced in 1976.

Differences in numbers of seabirds nesting in the five geographical regions of the South African coastline and at maritime islands and on the mainland during the three periods considered (late 1970s/early 1980s, late 1990s/early 2000s, late 2000s/early 2010s) were investigated using the $\chi^{2}$-test. In order to control for multiple testing, a false discovery rate adjustment was made to the probabilities $\left(\mathrm{P}_{i}\right)$ obtained for species $i$ for both the regional and island vs. mainland comparisons. Species were ranked in the order of ascending probability values and $\mathrm{P}_{i}$ were deemed significant at the $5 \%$ level $(q=0.05)$ for all $\mathrm{P}_{i} \leq(\mathrm{i} / \mathrm{N}) \cdot(\mathrm{q} / \mathrm{c}(\mathrm{N}))$, where $N=8$ and $\mathrm{c}(\mathrm{N})$ is the sum from $i=1$ to $\mathrm{N}$ of $1 / \mathrm{i}$ (Benjamini and Yekutieli, 2001).

\section{RESULTS}

Numbers of African penguins, Cape cormorants and bank cormorants in South Africa all showed a substantial decline from the late 1970s/early 1980s to the late 2000s/early 2010s (Table 1). There were large decreases in African penguins around South Africa, but the decrease in the Eastern Cape was proportionally less than in the Western Cape so that in 2013 it held marginally 
more penguins than the Western Cape (Figure 2). Most of the South African population of Cape cormorants breeds in the north and southwest sectors of the Western Cape, with $<1300$ pairs breeding in any other region (Supplementary Material). Between 1977 and 1981 and 2009 and 2013 there was a large decrease in numbers in the north Western Cape and a slight increase in the southwest of this province (Figure 2). New colonies were formed in the southwest Western Cape at Robben Island in 2004 and Stony Point in 2010 and in the east Western Cape at Knysna Heads in 2008 and all had subsequent rapid growth. In South Africa, numbers of bank cormorants decreased throughout the species' breeding range (Figure 2), which is west of Cape Agulhas (Cooper, 1981). The proportion of bank cormorants breeding in the southwest Western Cape increased from 41 to $43 \%$ during the 1900 s to $48 \%$ from 2011 to 2013.

The overall populations of crowned and white-breasted cormorants breeding around the west and south coasts of South Africa (Northern, Western and Eastern Cape provinces) were stable between 1977 and 1981 and 2008 and 2012 (Table 1). For both species, there were decreases in numbers breeding in all three regions west of Cape Agulhas, except for a large increase of crowned cormorants in the north Western Cape (Figure 2). Up until 1982, crowned cormorants were only known to breed west of Cape Agulhas, but in 2003 they extended breeding to the east sector of the Western Cape, where numbers increased from four pairs in 2003 to 33 pairs in 2012 (Whittington, 2004; Crawford
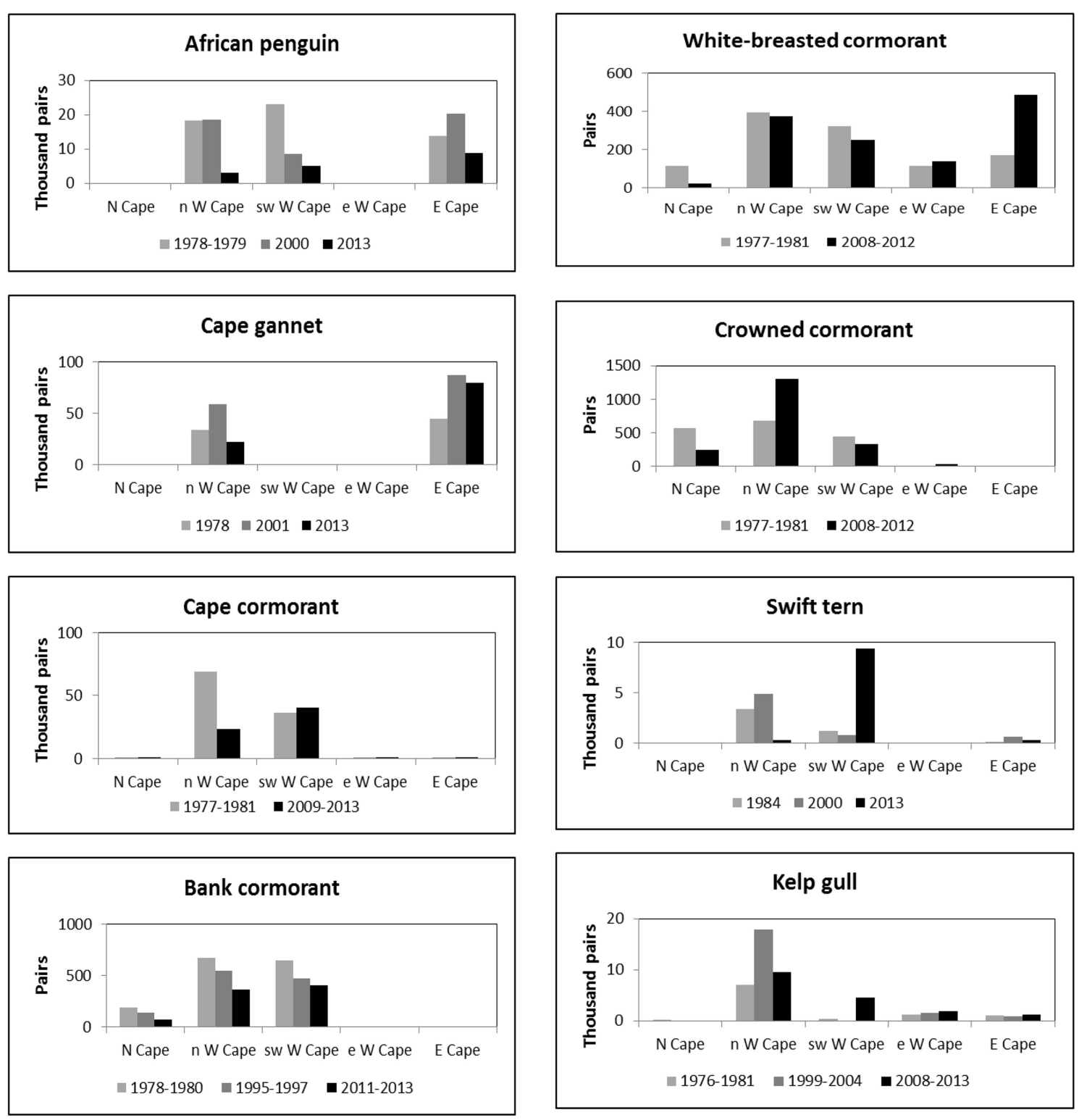

FIGURE 2 | Numbers of eight seabird species breeding coastally in five regions of South Africa's west and south coasts in different periods in which entire populations were estimated. 
et al., 2012). East of Cape Agulhas numbers of white-breasted cormorants breeding coastally increased between 1977 and 1981 and 2008 and 2012 (Figure 2; Crawford et al., 2013b).

The number of Cape gannets in South Africa increased between 1978 and 2001 but decreased in 2013 (Table 1). The species breeds at only three islands in South Africa, two of which are in the north Western Cape and the third in the Eastern Cape. Numbers increased in both regions between 1978 and 2001, but then decreased in the Western Cape (Figure 2). Swift terns increased rapidly in South Africa in the present century, with numbers more than doubling to peak at 14,000-16,000 pairs between 2008 and 2011 (Crawford et al., 2014b); then about 10,100 pairs bred in 2013 (Table 1). After 2005, numbers in the north Western Cape decreased markedly and most birds now breed in the southwest sector of this province (Figure 2). The South African population of kelp gulls more than doubled between 1976 and 1981 and the turn of the 21st century but have since fallen again (Table 1). After the turn of the century, numbers decreased in the north Western Cape but increased in each of the three regions farther south and east (Figure 2).

Between the three periods there were significant changes in the regional distributions of all eight seabird species (Table 2). After the late 1970s/early1980s, there were significant changes in numbers of seven seabirds breeding at maritime islands and on the mainland, the exception being white-breasted cormorants (Table 2). The proportions of birds breeding on the mainland increased for African penguin, bank cormorant, crowned cormorant and kelp gull and decreased for Cape gannet, Cape cormorant and swift tern (Figure 3).

\section{DISCUSSION}

Four of the seabirds considered in this paper (African penguin, Cape gannet, Cape cormorant, and swift tern) compete with the South African purse-seine fishery for anchovy and sardine, their main prey items (e.g., Crawford and Dyer, 1995). In South Africa, a fifth seabird (bank cormorant) feeds mainly on rock lobster, which is also targeted by a commercial fishery (Hockey et al., 2005; Cockcroft et al., 2008). Crowned cormorants eat mostly small, inshore fish species, notably Clinidae, that are not harvested by humans and do not contribute to the diets of fish that are (Crawford et al., 2012). White-breasted cormorants and kelp gulls are opportunistic feeders that do not compete substantially with fisheries for food and whose key prey species are not important dietary items for the main fish species harvested by humans (Crawford et al., 1987, 1991, 2013b; Steele, 1992; Whittington et al., 2006). Therefore, the prey of white-breasted and crowned cormorants and kelp gulls will not have been severely impacted by fisheries or have increased substantially as a result of fishing activities.

Off South Africa, the distributions of anchovy, sardine and rock lobster shifted south and east during the 1990s and early 2000s (Blamey et al., 2015). Similarly, for each of the four seabirds that feed mainly on anchovy and sardine, there were large recent decreases in the proportions of birds breeding off northwest South Africa (Northern Cape and north Western Cape) in the 1990s and/or 2000s (Figure 2; Crawford et al., 2014b). The proportion of bank cormorants breeding off northwest South Africa also decreased, but only by ca. $6 \%$.

The causes of the altered distributions of anchovy, sardine and rock lobster off South Africa are not fully understood. The eastward shift of anchovy spawners was attributed to improved conditions for spawning by this species to the east of Cape Agulhas (Roy et al., 2007). Differential growth and exploitation of sub-stocks of sardine occurring east and west of Cape Agulhas may have caused the shift in the distribution of this species, but environmentally mediated changes cannot be discarded (Cockcroft et al., 2008; Coetzee et al., 2008). The shift in the distribution of rock lobsters in the 1990s coincided with a decrease in lobster somatic growth rates and a major increase in the number and severity of lobster walkouts induced by low oxygen concentrations to the north of Dassen Island, indicating some underlying environmental cause (Cockcroft, 2001; Cockcroft et al., 2008).

Recent eastward extensions in the breeding ranges of two seabirds that are inshore feeders and do not compete with fisheries for food, crowned cormorant and Hartlaub's gull (L. hartlaubii), suggest some change in the environment (Whittington,

Table 2 | Results of $\chi^{2}$-tests used to examine the significance of changes in numbers of seabirds breeding in different regions and at maritime islands as opposed to the mainland.

\begin{tabular}{|c|c|c|c|c|c|c|}
\hline & \multicolumn{3}{|c|}{$\begin{array}{c}\text { Change in numbers breeding in } \\
\text { different regions }\end{array}$} & \multicolumn{3}{|c|}{$\begin{array}{l}\text { Change in numbers breeding on } \\
\text { maritime islands vs. the mainland }\end{array}$} \\
\hline & $x^{2}$ & $d f$ & $P<0.05$ & $x^{2}$ & $d f$ & $P<0.05$ \\
\hline African penguin & 8319 & 4 & Yes & 6071 & 2 & Yes \\
\hline Cape gannet & 100354 & 2 & Yes & 101778 & 2 & Yes \\
\hline Cape cormorant & 13002 & 4 & Yes & 10755 & 1 & Yes \\
\hline Bank cormorant & 16 & 4 & Yes & 14 & 2 & Yes \\
\hline Crowned cormorant & 351 & 3 & Yes & 14632 & 1 & Yes \\
\hline White-breasted cormorant & 222 & 4 & Yes & 5 & 1 & No \\
\hline Swift tern & 26521 & 4 & Yes & 10209 & 2 & Yes \\
\hline Kelp gull & 730753 & 8 & Yes & 1846 & 2 & Yes \\
\hline
\end{tabular}

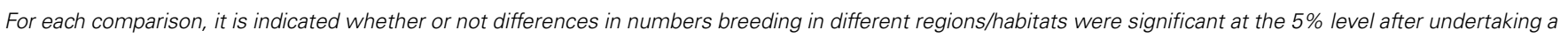
false discovery rate adjustment. 

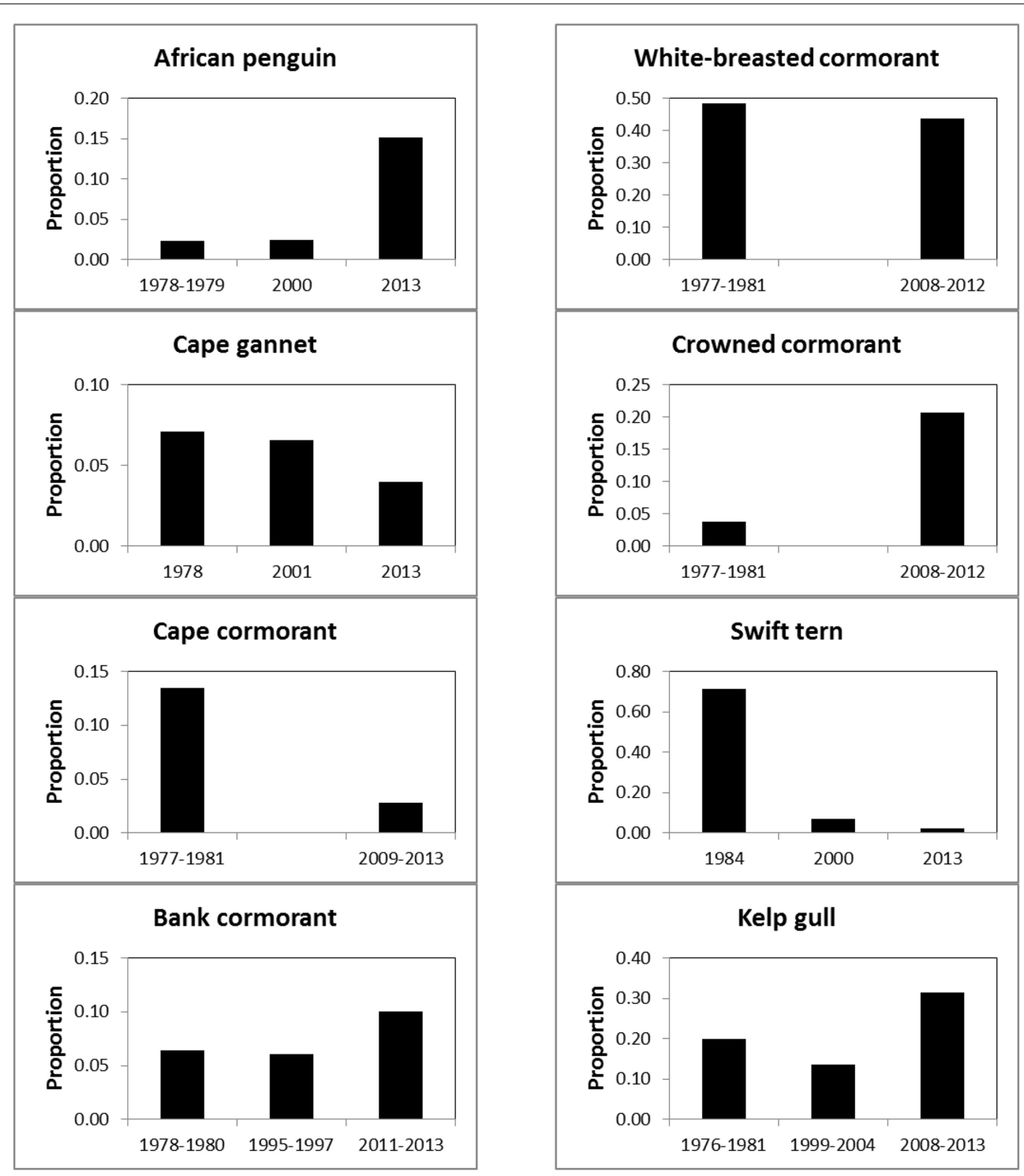

FIGURE 3 | Proportions of eight seabirds breeding on South Africa's mainland, as opposed to its maritime islands, during 1977-1984, 1995-2004, and 2008-2013.

2004; Crawford et al., 2008d), as do the anti-clockwise shifts to the south and east around the South African coast in the proportions of the three seabirds considered here that do not compete substantially with fisheries for prey (Figure 2; Crawford et al., 2013b; Whittington et al., in press). Kelp gulls may scavenge from fishing boats (Whittington et al., 2006), but the food of crowned cormorants, mainly small fish that occur inter-tidally or inshore sub-tidally (Crawford et al., 2012), and of white-breasted cormorants, mainly inshore and estuarine fish species (Crawford et al., 2013b), is unlikely to be influenced by commercial fishing activities. Although other factors, such as disturbance and predation, may have influenced decreases of white-breasted cormorants and kelp gulls off northwest South Africa (Crawford et al., 2013b; Whittington et al., in press), there was a concurrent extension in the range of the cool-water, kelp-bed forming seaweed Ecklonia maxima to the east of Cape Agulhas (Bolton et al., 2012) suggesting a cooling of the environment in the vicinity of Cape Agulhas. Prior to this extension, the breeding range of bank cormorants was broadly related to that of E. maxima (Cooper, 1981).

Amongst the seabirds that compete with South Africa's purseseine fishery for anchovy and sardine there was a varied response to the altered distributions of these forage species. Populations of Cape gannets and swift terns showed marked increases, whereas those of African penguins and Cape cormorants decreased by more than $50 \%$ and ca. $40 \%$, respectively (Table 1 ). The success of gannets is attributable to a large increase in its easternmost colony at Bird Island in Algoa Bay, which may have been aided by immigration of first-time breeders from decreasing western colonies (Crawford et al., 2007, 2014b). Swift terns are nomadic between breeding colonies, which gives them the ability to adapt 
to an altered distribution of their prey (Crawford et al., 2002), and they likely had good breeding success in the 2000s (Crawford, 2009). By contrast, marine top predators that exhibit behavioral inertia are at greater risk from environmental change (Pichegru et al., 2010b). Breeding African penguins show high fidelity to their partners and hence to breeding localities (Randall, 1989; Crawford et al., 1995). Although Cape cormorants may move between breeding localities (Crawford et al., 1994), they also show fidelity to natal and nest sites (Berry, 1977; Hockey et al., 2005). Both African penguins and Cape cormorants have a restricted foraging range when breeding (e.g., Heath and Randall, 1989; Pichegru et al., 2010a; Hamann et al., 2012) and they suffered high adult mortality in the 1990s and 2000s in periods of prey scarcity off western South Africa (Crawford et al., 1992, 2011; Waller and Underhill, 2007; Sherley et al., 2014). Cape gannets have a much greater foraging range during breeding (Lewis et al., 2006) and supplement their diet by feeding on offal discarded by fisheries when their natural prey is scarce, thereby buffering adult survival (e.g., Berruti et al., 1993; Pichegru et al., 2007; Grémillet et al., 2008; Distiller et al., 2012; Crawford et al., 2014b).

Bank cormorants, which compete with the rock lobster fishery, may move short distances between breeding localities (Crawford et al., 1999) but are relatively sedentary, the maximum recorded movement of birds older than 1 year being $168 \mathrm{~km}$ (Cooper, 1981). They are benthic feeders that in Namibia foraged up to $9 \mathrm{~km}$ from a breeding locality in waters less than $50 \mathrm{~m}$ deep (Ludynia et al., 2010). Although rock lobsters have not shifted their distribution to the same extent as anchovy and sardine, their reduced populations off northwest South Africa appear to have been insufficient to support formerly large colonies of bank cormorants in this region (Crawford et al., 2008a). Recent nest failures for bank cormorants at Robben Island were related to wave heights and air temperature, with chick survival being reduced in years when major storm events occurred during breeding and destroyed nests (Sherley et al., 2012b).

The considerably better recent performance off western South Africa of the two cormorants that do not compete with fisheries for prey than the two that do and the African penguin (Figure 2) highlights the possibility that fishing substantially reduced prey availability off northwest South Africa following displacement of the three forage resources to the south and east. Unfortunately for the affected seabirds, many fish processing plants were located off northwest South Africa and fishers continued to seek fish near to their factories. This may have exacerbated the local depletion of prey (e.g., Crawford et al., 2008c; Durant et al., 2010). The exploitation rate of sardine west of Cape Agulhas showed a substantial increase in the mid-2000s (Coetzee et al., 2008). Off Peru, local depletion of anchovy (E. ringens) by fishing had a negative impact on foraging parameters of Peruvian boobies (Sula variegata) that competed with the fishery for food (Bertrand et al., 2012).

Equally unfortunately for the affected seabirds, the displacement of forage resources to the south and east brought about a mismatch in the distributions of the breeding localities and prey of the seabirds (Crawford et al., 2008c). There are no large islands at which seabirds may breed between Robben and Dyer islands off southwest South Africa and then a distance of about $600 \mathrm{~km}$ to the seabird islands in Algoa Bay (Figure 1). Consequently, several seabirds, including African penguin and bank cormorant, appear to have attempted to offset the mismatch of colonies and food by breeding in increasing proportions on the mainland (Figure 3). The decreases in the number of Cape gannets, Cape cormorants and swift terns breeding on the mainland is mainly attributable to decreases in numbers at the two islands in the north Western Cape that were joined to the mainland and hence assumed to be part of the mainland-Cape gannets and Cape cormorants at Bird Island (Lambert's Bay) and swift terns at Marcus Island (Table 1; Crawford et al., 2007; Crawford, 2009). However, substantial numbers of Cape cormorants have joined African penguins and bank cormorants in breeding at the southern mainland locality of Stony Point and they formed a new colony at Knysna Heads (Supplementary Material; Crawford et al., 2011).

A better understanding of the mechanisms driving seabird populations in South Africa will result from development of integrated population models that account for movement between colonies (e.g., Sherley et al., 2014) and of models that account for multiple factors that may be influencing populations. The former are hampered to some extent by insufficient mark-recapture information properly to estimate survival and rates of migration between regions for some species and age classes of birds (e.g., Distiller et al., 2012). Progress has been made on developing a systems dynamics approach to modeling multiple drivers of African penguin populations that uses expert opinion in the absence of quantitative information (e.g., Ludynia et al., 2014; Weller et al., 2014). Developing new technology, e.g., remotely operated drones, may prove useful in obtaining more frequent information on numbers of seabirds breeding at localities that are difficult to access and hence reducing the uncertainty of population estimates.

Potential mechanisms to mitigate the adverse impacts of environmental change on seabirds off South Africa are implementation of spatial management for fisheries of shared forage resources, including both allocations of catch limits at a regional scale and localized closures to fishing around impacted seabird colonies (e.g., Durant et al., 2010; Pichegru et al., 2010a, 2012), and offsetting the present mismatch of breeding localities and food through establishing new seabird colonies nearer the present location of food (e.g., Department of Environmental Affairs, 2013). Penguins attempted to form a new colony on the southern mainland east of Cape Agulhas between 2003 and 2007 but were prevented from doing so by indigenous carnivores (Crawford et al., 2011), whereas at Knysna Heads Cape cormorants were more successful (Supplementary Material). Given the known frequency of formation of new colonies by different species and their use of man-made structures and habitats for breeding, establishment of new colonies may be easier for cormorants, gulls and terns (Supplementary Material; Crawford, 2009; Crawford et al., 2012, 2013b; Whittington et al., in press) than for penguins (Crawford et al., 2013a) and especially gannets (Crawford et al., 1983).

With regard to the Cape gannet, it is noteworthy that there has been a long-term redistribution to the south and east of its breeding population. Whereas $80 \%$ of Cape gannets bred in Namibia in the 1950s and 1960s, at present about $90 \%$ breed 
in South Africa (Crawford et al., 2007, 2014b). Within South Africa, the proportion breeding in the Eastern Cape, which now supports about $70 \%$ of the global population (Crawford et al., 2014b), has increased. As Algoa Bay is at the eastern extremity of the greater Benguela upwelling region, juxtaposed to the warm, south-west flowing Agulhas Current (Hutchings et al., 2009), which is likely to be unsuitable habitat for the gannets, there appears to be no further opportunity for the species to expand its range to the east. Similar difficulties in adjusting distributions to an altered environment can be expected, for example, for less mobile seabirds such as Crozet shags (Phalacrocorax [atriceps] melanogenis) and Gentoo penguins, and perhaps even more wide-ranging species such as rockhopper penguins, at the wellseparated archipelagos of the sub-Antarctic (e.g., Crawford et al., 2008b, 2014a; Allan et al., 2013). In such instances, human interventions to mitigate adverse impacts of climate change will not prove easy and may best be directed at attempting to maintain the substantially reduced abundances of seabirds that have survived changes to date. Certainly conservation planning will be aided by a better understanding of the ultimate causes of the distributional changes.

\section{ACKNOWLEDGMENTS}

We thank Bruce Dyer, Deon Geldenhuys, Nick Hanekom, Cuan McGeorge, Leshia Upfold, Johan Visagie and all others who assisted with the counts of Cape and bank cormorants. We thank our departments and the National Research Foundation (incentive programme) for funding this research and providing logistical support and the two reviewers for greatly improving this manuscript. We thank NISC (Pty) Ltd for permission to reproduce Figure 1 as an amendment of a Figure published in Ostrich in Crawford et al. (2014b).

\section{SUPPLEMENTARY MATERIAL}

The Supplementary Material for this article can be found online at: http://www.frontiersin.org/journal/10.3389/fevo.2015.00010/ abstract

\section{REFERENCES}

Allan, E. L., Froneman, W., Durgadoo, J. V., McQuaid, C. D., Ansorge, I. J., and Richoux, N. B. (2013). Critical indirect effects of climate change on subAntarctic ecosystem functioning. Ecol. Evol. 3, 2994-3004. doi: 10.1002/ece3.678

Benjamini, Y., and Yekutieli, D. (2001). The control of the false discovery rate in multiple testing under dependency. Ann. Stat. 29, 1165-1188. doi: 10.1214/aos/1013699998

Berruti, A., Underhill, L. G., Shelton, P. A., Moloney, C., and Crawford, R. J. M. (1993). Seasonal and interannual variation in the diet of two colonies of the Cape gannet Morus capensis between 1977/1978 and 1989. Colon. Waterbird. 16, 158-175. doi: 10.2307/1521434

Berry, H. H. (1977). Seasonal fidelity of Cape cormorants to nesting area. Cormorant 2, 5-6.

Bertrand, S., Joo, R., Smet, C. A., Tremblay, Y., Barbraud, C., and Weimerskirch, H. (2012). Local depletion by a fishery can affect seabird foraging. J. Appl. Ecol. 49, 1168-1177. doi: 10.1111/j.1365-2664.2012.02190.x

BirdLife International. (2010). Rockhopper Penguins: A Plan for Research and Conservation Action to Investigate and Address Population Changes. Great Britain: BirdLife International.

BirdLife International. (2014). Species Factsheet: Phalacrocorax Carbo. Available online at: http://www.birdlife.org on 27/10/2014

Blamey, L. K., Howard, J. A. E., Agenbag, J., and Jarre, A. (2012). Regime-shifts in the southern Benguela shelf and inshore region. Prog. Oceanogr. 106, 80-95. doi: 10.1016/j.pocean.2012.07.001
Blamey, L. K., Shannon, L. J., Bolton, J. J., Crawford, R. J. M., Dufois, D., EversKing, H., et al. (2015). Ecosystem changes in the southern Benguela and the underlying processes. J. Mar. Syst. 144, 9-29. doi: 10.1016/j.jmarsys.2014.11.006

Bolton, J. J., Anderson, R. J., Smot, A. J., and Rothman, M. D. (2012). South African kelp moving eastwards: the discovery of Ecklonia maxima (Osbeck) Papenfuss at De Hoop Nature Reserve on the south coast of South Africa. Afr. J. Mar. Sci. 34, 147-151. doi: 10.2989/1814232X.2012.675125

Brooke, R. K., Cooper, J., Shelton, P. A., and Crawford, R. J. M. (1982). Taxonomy, distribution, population size, breeding and conservation of the whitebreasted cormorant, Phalacrocorax carbo, on the southern African coast. Le Gerfaut 72, 189-220.

Cheung, W. W. L., Lam, V. W. Y., Sarmiento, J. L., Kearney, K., Watson, R., and Pauly, D. (2009). Projecting global marine biodiversity impacts under climate change scenarios. Fish Fish. 10, 235-251. doi: 10.1111/j.1467-2979.2008.00315.x

Cockcroft, A. C. (2001). Jasus lalandii 'walkouts' or mass strandings in South Africa during the 1990s: an overview. Mar. Freshw. Res. 52, 1085-1094. doi: 10.1071/MF01100

Cockcroft, A. C., and MacKenzie, A. J. (1997). The recreational fishery for West Coast rock lobster Jasus lalandii in South Africa. Afr. J. Mar. Sci. 30, 149-159. doi: 10.2989/AJMS.2008.30.1.15.465

Cockcroft, A. C., van Zyl, D., and Hutchings, L. (2008). Large-scale changes in the spatial distribution of South African West Coast rock lobsters: an overview. Afr. J. Mar. Sci. 30, 149-159. doi: 10.2989/AJMS.2008.30.1.15.465

Coetzee, J. C., van der Lingen, C. D., Hutchings, L., and Fairweather, T. P. (2008). Has the fishery contributed to a major shift in the distribution of South African sardine? ICES J. Mar. Sci. 65, 1676-1688. doi: 10.1093/icesjms/fsn184

Cooper, J. (1981). Biology of the bank cormorant, part 1: distribution, population size, movements and conservation. Ostrich 52, 208-215. doi: 10.1080/00306525.1981.9633608

Cooper, J., Brooke, R. K., Shelton, P. A., and Crawford, R. J. M. (1982). Distribution, population size and conservation of the Cape cormorant Phalacrocorax capensis. Fish. Bull. S. Afr. 16, 121-143.

Cooper, J., Crawford, R. J. M., Suter, W., and Williams, A. J. (1990). Distribution, population size and conservation of the swift tern Sterna bergii in southern Africa. Ostrich 61, 56-65. doi: 10.1080/00306525.1990.9633939

Crawford, R. J. M. (2007). Food, fishing and seabirds in the Benguela upwelling system. J. Ornithol. 148, S253-S260. doi: 10.1007/s10336-007-0228-z

Crawford, R. J. M. (2009). A recent increase of swift terns Thalasseus bergii off South Africa - the possible influence of an altered abundance and distribution of prey. Prog. Oceanogr. 83, 398-403. doi: 10.1016/j.pocean.2009.07.021

Crawford, R. J. M. (2013). Long-term change in the population sizes and conservation status of southern African seabirds. Ostrich 84, v-ix. doi: 10.2989/00306525.2013.819661

Crawford, R. J. M., Allwright, D. M., and Heyl, C. W. (1992). High mortality of Cape cormorants (Phalacrocorax capensis) off western South Africa in 1991 caused by Pasteurella multocida. Colon. Waterbird. 15, 236-238. doi: $10.2307 / 1521458$

Crawford, R. J. M., Altwegg, R., Barham, B. J., Barham, P. J., Durant, J. M., Dyer, B. M., et al. (2011). Collapse of South Africa's penguins in the early 21 st century: a consideration of food availability. Afr. J. Mar. Sci. 33, 139-156. doi: 10.2989/1814232X.2011.572377

Crawford, R. J. M., Barham, P. J., Underhill, L. G., Shannon, L. J., Coetzee, J. C., Dyer, B. M., et al. (2006). The influence of food availability on breeding success of African penguins Spheniscus demersus at Robben Island, South Africa. Biol. Conserv. 132, 119-125. doi: 10.1016/j.biocon.2006.03.019

Crawford, R. J. M., Boonstra, H. G. v. D., Dyer, B. M., and Upfold, L. (1995). "Recolonization of Robben Island by African penguins, 1983-1992," in The Penguins: Ecology and Management, eds P. Dann, I. Norman, and P. Reilly (Chipping Norton: Surrey Beatty), 333-363.

Crawford, R. J. M., Cockroft, A. C., Dyer, B. M., and Upfold, L. (2008a). Divergent trends in bank cormorants Phalacrocorax neglectus breeding in South Africa's Western Cape consistent with a distributional shift of rock lobsters Jasus lalandii. Afr. J. Mar. Sci. 30, 161-166. doi: 10.2989/AJMS.2008.30.1.16.466

Crawford, R. J. M., Cooper, J., Dyer, B. M., Upfold, L., Venter, A. D., Whittington, P. A., et al. (2002). Longevity, inter-colony movements and breeding of crested terns in South Africa. Emu 102, 1-9. doi: 10.1071/MU01009

Crawford, R. J. M., Cooper, J., and Shelton, P. A. (1982a). Distribution, population size, breeding and conservation of the kelp gull in southern Africa. Ostrich 53, 164-177. doi: 10.1080/00306525.1982.9634747 
Crawford, R. J. M., Dundee, B. L., Dyer, B. M., Klages, N. T. W., Meÿer, M. A., and Upfold, L. (2007). Trends in numbers of Cape gannets (Morus capensis), 1956/57-2005/06, with a consideration of the influence of food and other factors. ICES J. Mar. Sci. 64, 169-177. doi: 10.1093/icesjms/fsl011

Crawford, R. J. M., and Dyer, B. M. (1995). Responses by four seabirds to a fluctuating availability of Cape anchovy Engraulis capensis off South Africa. Ibis 137, 329-339. doi: 10.1111/j.1474-919X.1995.tb08029.x

Crawford, R. J. M., Dyer, B. M., and Brooke, R. K. (1994). Breeding nomadism in southern African seabirds constraints, causes and conservation. Ostrich 65, 231-246. doi: 10.1080/00306525.1994.9639687

Crawford, R. J. M., Dyer, B. M., Cordes, I., and Williams, A. J. (1999). Seasonal pattern of breeding, population trend and conservation status of bank cormorants Phalacrocorax neglectus off southwestern Africa. Biol. Conserv. 87, 49-58. doi: 10.1016/S0006-3207(98)00042-1

Crawford, R. J. M., Dyer, B. M., Geldenhuys, D., Makhado, A. B., Randall, R. M., Upfold, L., et al. (2012). Trends in numbers of crowned cormorants in South Africa, with information on diet. Afr. J. Mar. Sci. 34, 411-424. doi: 10.2989/1814232X.2012.716373

Crawford, R. J. M., Dyer, B. M., Upfold, L., and Makhado, A. B. (2014a). Congruent, decreasing trends of Gentoo penguins and Crozet shags at sub-Antarctic Marion Island suggest food limitation through common environmental forcing. Afr. J. Mar. Sci. 36, 225-231. doi: 10.2989/1814232X.2014.926293

Crawford, R. J. M., Kemper, J., and Underhill, L. G. (2013a). "African penguin (Spheniscus demersus)," in Penguins Natural History and Conservation, eds P. Garcia Borboroglu, and P. D. Boersma (Seattle, WA: University of Washington Press), 211-231.

Crawford, R. J. M., Makhado, A. B., Upfold, L., and Dyer, B. M. (2008b). Mass on arrival of rockhopper penguins at Marion Island correlated with breeding success. Afr. J. Mar. Sci. 30, 185-188. doi: 10.2989/AJMS.2008.30.1.19.469

Crawford, R. J. M., Makhado, A. B., Waller, L. J., and Whittington, P. A. (2014b). Winners and losers-responses to recent environmental change by South African seabirds that compete with purse-seine fisheries for food. Ostrich 85, 111-117. doi: 10.2989/00306525.2014.955141

Crawford, R. J. M., Randall, R. M., Whittington, P. A., Waller, L. J., Dyer, B. M., Allan, D. G., et al. (2013b). South Africa's coastal-breeding white-breasted cormorants: population trends, breeding season and movements, and diet. Afr. J. Mar. Sci. 35, 473-490. doi: 10.2989/1814232X.2013.845603

Crawford, R. J. M., Ryan, P. G., and Williams, A. J. (1991). Seabird consumption and production in the Benguela and western Agulhas ecosystems. S. Afr. J. Mar. Sci. 11, 357-375. doi: 10.2989/025776191784287709

Crawford, R. J. M., Sabarros, P. S., Fairweather, T., Underhill, L. G., and Wolfaardt, A. C. (2008c). Implications for seabirds off South Africa of a long-term change in the distribution of sardine. Afr. J. Mar. Sci. 30, 177-184. doi: 10.2989/AJMS.2008.30.1.18.468

Crawford, R. J. M., Shannon, L. V., and Pollock, D. E. (1987). The Benguela ecosystem. Part IV. The major fish and invertebrate resources. Oceanog. Mar. Biol. Ann. Rev. 25, 353-505.

Crawford, R. J. M., Shelton, P. A., Brooke, R. K., and Cooper, J. (1982b). Taxonomy, distribution, population size and conservation of the crowned cormorant Phalacrocorax coronatus. Le Gerfaut 72, 3-30.

Crawford, R. J. M., Shelton, P. A., Cooper, J., and Brooke, R. K. (1983). Distribution, population size and conservation of the Cape gannet Morus capensis. S. Afr. J. Mar. Sci. 1, 153-174. doi: 10.2989/025776183784447458

Crawford, R. J. M., Tree, A. J., Whittington, P. A., Visagie, J., Upfold, L., Roxburg, K. J., et al. (2008d). Recent distributional changes of seabirds in South Africa: is climate having an impact? Afr. J. Mar. Sci. 30, 189-193. doi: 10.2989/AJMS.2008.30.1.20.470

Crawford, R. J. M., Underhill, L. G., Altwegg, R., Dyer, B. M., and Upfold, L. (2009a). Trends in numbers of kelp gulls Larus dominicanus off western South Africa, 1978-2007. Ostrich 80, 139-143. doi: 10.2989/OSTRICH.2009.80.3.3.966

Crawford, R. J. M., Whittington, P. A., Martin, A. P., Tree, A. J., and Makhado, A. B. (2009b). Population trends of seabirds breeding in South Africa's Eastern Cape, and the possible influence of anthropogenic and environmental change. Mar. Ornithol. 37, 159-174.

Department of Environmental Affairs. (2013). Biodiversity Management Plan for the African penguin Spheniscus demersus. S. Af. Gov. Gaz. 580, 1-64.

Distiller, G., Altwegg, R., Crawford, R. J. M., Klages, N. T. W., and Barham, B. (2012). Factors affecting adult survival and inter-colony movement at the three
South African colonies of Cape gannet. Mar. Ecol. Prog. Ser. 461, 245-255. doi: 10.3354/meps09807

Durant, J. M., Crawford, R. J. M., Wolfaardt, A. C., Agenbag, C. J., Visagie, J., Upfold, L., et al. (2010). Influence of feeding conditions on breeding of African penguins -importance of adequate local food supplies. Mar. Ecol. Prog. Ser. 420, 263-271. doi: 10.3354/meps08857

Fairweather, T. P., van der Lingen, C. D., Booth, A. J., Drapeau, L., and van der Westhuizen, J. J. (2006). Indicators of sustainable fishing for South African sardine (Sardinops sagax) and anchovy (Engraulis encrasicolus). Afr. J. Mar. Sci. 28, 661-680. doi: 10.2989/18142320609504215

Fischbach, A. S., Amstrup, S. C., and Douglas, D. C. (2007). Landward and eastward shift of Alaskan polar bear denning associated with recent sea ice changes. Polar Biol. 30, 1395-1405. doi: 10.1007/s00300-007-0300-4

Gammelsrød, T., Bartholomae, C. H., Boyer, D. C., Filipe, V. L. L., and O’Toole, M. J. (1998). Intrusion of warm surface water along the Angolan-Namibian coast in February-March 1995: the 1995 Benguela Niño. S. Afr. J. Mar. Sci. 19, 41-56.

Grémillet, D., Pichegru, L., Kuntz, G., Woakes, A. G., Wilkinson, S., Crawford, R. J. M., et al. (2008). A junk-food hypothesis for gannets feeding on fishery waste. Proc. Roy. Soc. London Bio. Ser. 18, 1-8. doi: 10.1098/rspb.2007.1763

Hamann, M. H., Grémillet, D., Ryan, P. G., Bonadonna, F., van der Lingen, C. D., and Pichegru, L. (2012). A hardknock life: the foraging ecology of Cape cormorants amidst shifting prey resources and industrial fishing pressure. Afr. J. Mar. Sci. 34, 233-240. doi: 10.2989/1814232X.2012.709960

Heath, R. G. M., and Randall, R. M. (1989). Foraging ranges and movements of jackass penguins (Spheniscus demersus) established through radio telemetry. J. Zool. 217, 367-379. doi: 10.1111/j.1469-7998.1989.tb02496.x

Hockey, P. A. R., Dean, W. R. J., and Ryan, P. G. (eds). (2005). Roberts Birds of Southern Africa, 7th Edn. Cape Town: John Voelcker Bird Book Fund.

Hutchings, L., van der Lingen, C., Shannon, L. J., Crawford, R. J. M., Verheye, H. M. S., Bartholomae, C. H., et al. (2009). The Benguela Current: an ecosystem of four components. Prog. Oceanogr. 83, 15-32. doi: 10.1016/j.pocean.2009. 07.046

Kirkman, S. P., Yemane, D., Oosthuizen, W. H., Meÿer, M. A., Kotze, P. G. H., Skrypzeck, H., et al. (2012). Spatio-temporal shifts of the dynamic Cape fur seal population in southern Africa, based on aerial censuses (1972-2009). Mar. Mamm. Sci. 29, 497-524. doi: 10.1111/j.1748-7692.2012.00584.x

Lewis, S., Grémillet, D., Daunt, F., Ryan, P. G., Crawford, R. J. M., and Wanless, S. (2006). Using behavioural and state variables to identify proximate causes of population change in a seabird. Oecologia 147, 606-614. doi: 10.1007/s00442005-0321-z

Ludynia, K., Jones, R., Kemper, J., Garthe, S., and Underhill, L. G. (2010). Foraging behaviour of bank cormorants in Namibia: implications for conservation. Endangered Species Res. 12, 31-40. doi: 10.3354/esr00288

Ludynia, K., Waller, L. J., Sherley, R. B., Abadi, F., Galada, Y., Geldenhuys, D., et al. (2014). Processes influencing the population dynamics and conservation of African penguins on Dyer Island, South Africa. Afr. J. Mar. Sci. 36, 253-267. doi: 10.2989/1814232X.2014.929027

Lynch, H. J. (2013). "Gentoo penguin (Pygoscelis papua)," in Penguins Natural History and Conservation, eds P. García Borboroglu and P. D. Boersma (Seattle, WA: University of Washington Press), 73-88.

Lynch, H. J., Naveen, R., Trathan, P. N., and Fagan, W. F. (2012). Spatially integrated assessment reveals widespread changes in penguin populations on the Antarctic Peninsula. Ecology 93, 1367-1377. doi: 10.1890/11-1588.1

Moloney, C. L., Fennessy, S. T., Gibbons, M. J., Roychoudhury, A., Shillington, F. A., von der Heyden, B. P., et al. (2013). Reviewing evidence of marine ecosystem change off South Africa. Afr. J. Mar. Sci. 35, 427-448. doi: 10.2989/1814232X.2013.836135

Pichegru, L., Grémillet, D., Crawford, R. J. M., and Ryan, P. G. (2010a). Marine no-take zone rapidly benefits Endangered penguin. Biol. Lett. 6, 498-501. doi: 10.1098/rsbl.2009.0913

Pichegru, L., Ryan, P. G., Crawford, R. J. M., van der Lingen, C. D., and Grémillet, D. (2010b). Behavioural inertia places a marine top predator at risk from environmental change in the Benguela upwelling system. Mar. Biol. 157, 537-544. doi: 10.1007/s00227-009-1339-2

Pichegru, L., Ryan, P. G., van der Lingen, C. D., Coetzee, J., Ropert-Coudert, Y., and Grémillet, D. (2007). Foraging behaviour and energetics of Cape gannets Morus capensis feeding on live prey and fishery discards in the Benguela upwelling system. Mar. Ecol. Prog. Ser. 350, 127-136. doi: 10.3354/ meps07128 
Pichegru, L., Ryan, P. G., van Eeden, R., Reid, T., Grémillet, D., and Wanless, R. (2012). Industrial fishing, no-take zones and endangered penguins. Biol. Conserv. 156, 117-125. doi: 10.1016/j.biocon.2011.12.013

Randall, R. M. (1989). "Jackass penguins," in Oceans of Life off Southern Africa, eds A. I. L. Payne and R. J. M. Crawford (Cape Town: Vlaeberg Publishers), 244-256.

Roy, C., van der Lingen, C. D., Coetzee, J. C., and Lutjeharms, J. R. E. (2007). Abrupt environmental shift associated with changes in the distribution of Cape anchovy Engraulis encrasicolus spawners in the southern Benguela. Afr. J. Mar. Sci. 29, 309-319. doi: 10.2989/AJMS.2007.29.3.1.331

Sabarros, P. S., Durant, J. M., Grémillet, D., Crawford, R. J. M., and Stenseth, N. C. (2012). Seabird community ecology_differential responses of three sympatric marine predators to spatio-temporal variability of shared resources. Mar. Ecol. Prog. Ser. 468, 291-301. doi: 10.3354/meps09972

Shelton, P. A., Crawford, R. J. M., Cooper, J., and Brooke, R. K. (1984). Distribution, population size and conservation of the jackass penguin Spheniscus demersus. S. Afr. J. Mar. Sci. 2, 217-257. doi: 10.2989/02577618409504370

Sherley, R. B., Abadi, F., Ludynia, K., Barham, B. J., Clark, A. E., and Altwegg, R. (2014). Age-specific survival and movement among major African penguin Spheniscus demersus colonies. Ibis. 156, 716-728. doi: 10.1111/ibi.12189

Sherley, R. B., Barham, B. J., Barham, P. J., Leshoro, T. M., and Underhill, L. G. (2012a). Artificial nests enhance the breeding productivity of African penguins (Spheniscus demersus) on Robben Island, South Africa. Emu 112, 97-106. doi: 10.1071/MU11055

Sherley, R. B., Ludynia, K., Underhill, L. G., Jones, R., and Kemper, J. (2012b). Storms and heat limit the nest success of bank cormorants: implications of future climate change for a surface-nesting seabird in southern Africa. J. Ornithol. 153, 441-455. doi: 10.1007/s10336-011-0760-8

Sherley, R. B., Underhill, L. G., Barham, B. J., Barham, P. J., Coetzee, J. C., Crawford, R. J. M., et al. (2013). Influence of local and regional prey availability on breeding performance of African penguins Spheniscus demersus. Mar. Ecol. Prog. Ser. 473, 291-301. doi: 10.3354/meps 10070

Steele, W. K. (1992). Diet of Hartlaub's gull Larus hartlaubii and the kelp gull L. dominicanus in the southwestern Cape Province, South Africa. Ostrich 63, 68-82. doi: 10.1080/00306525.1992.9633952

Tarr, R. J. Q., Williams, P. V. G., and MacKenzie, L. (1992). Abalone, sea urchins and rock lobster: a possible ecological shift that may affect traditional fisheries. S. Afr. J. Mar. Sci. 17, 319-323. doi: 10.2989/025776196784158455

Trivelpiece, W. Z., Hinke, J. T., Miller, A. K., Reiss, C. S., Trivelpiece, S. G., and Watters, G. M. (2011). Variability in krill biomass links harvesting and climate warming to penguin population changes in Antarctica. Proc. Natl Acad. Sci. U.S.A. 108, 7625-7628. doi: 10.1073/pnas.1016560108

Underhill, L. G., Crawford, R. J. M., Wolfaardt, A. C., Whittington, P. A., Dyer, B. M., Leshoro, T. M., et al. (2006). Regionally coherent trends in colonies of African penguins Spheniscus demersus in the Western Cape, South Africa, 1987-2005. Afr. J. Mar. Sci. 28, 697-704. doi: 10.2989/181423 20609504218

van der Lingen, C. D., Shannon, L. J., Cury, P., Kreiner, A., Moloney, C. L., Roux, J.-P., et al. (2006). "Resource and ecosystem variability, including regime shifts," in The Benguela Current System, Benguela: Predicting a Large Marine Ecosystem, eds V. Shannon, G. Hempel, P. Malanotte-Rizzoli, C. Moloney, and J. Woods (Amsterdam: Elsevier), 147-184.

Waller, L. J., and Underhill, L. G. (2007). Management of avian cholera Pasteurella multocida outbreaks on Dyer Island, South Africa, 2002-2005. Afr. J. Mar. Sci. 29, 105-111. doi: 10.2989/AJMS.2007.29.1.9.74

Weller, F., Cecchini, L.-A., Shannon, L. J., Sherley, R. B., Crawford, R. J. M., Altwegg, R., et al. (2014). A system dynamics approach to modelling multiple drivers of the African penguin population on Robben Island, South Africa. Ecol. Modell. 277, 38-56. doi: 10.1016/j.ecolmodel.2014.01.013

Whittington, P. A. (2004). New breeding locality for crowned cormorant. Koedoe 47, 125-126. doi: 10.4102/koedoe.v47i2.87

Whittington, P. A., Crawford, R. J. M., Martin, A. P., Randall, R. M., Brown, M., Makhado, A. B., et al. (in press). Recent trends of the kelp gull Larus dominicanus in South Africa. Waterbirds.

Whittington, P. A., Martin, A. P., and Klages, N. T. W. (2006). Status, distribution and conservation implications of the kelp gull (Larus dominicanus vetula) within the Eastern Cape region of South Africa. Emu 106, 127-139. doi: 10.1071/MU05049

Conflict of Interest Statement: The authors declare that the research was conducted in the absence of any commercial or financial relationships that could be construed as a potential conflict of interest.

Received: 13 November 2014; accepted: 28 January 2015; published online: 18 February 2015.

Citation: Crawford RJM, Makhado AB, Whittington PA, Randall RM, Oosthuizen WH and Waller LJ (2015) A changing distribution of seabirds in South Africa-the possible impact of climate and its consequences. Front. Ecol. Evol. 3:10. doi: 10.3389/ fevo.2015.00010

This article was submitted to Interdisciplinary Climate Studies, a section of the journal Frontiers in Ecology and Evolution.

Copyright (c) 2015 Crawford, Makhado, Whittington, Randall, Oosthuizen and Waller. This is an open-access article distributed under the terms of the Creative Commons Attribution License (CC BY). The use, distribution or reproduction in other forums is permitted, provided the original author(s) or licensor are credited and that the original publication in this journal is cited, in accordance with accepted academic practice. No use, distribution or reproduction is permitted which does not comply with these terms. 